\title{
A missense variant of the ATP1A2 gene is associated with a novel phenotype of progressive sensorineural hearing loss associated with migraine
}

\author{
Se-Kyung Oh ${ }^{1,2,11}$, Jeong-In Baek ${ }^{1,3,11}$, Karl M Weigand ${ }^{4}$, Hanka Venselaar ${ }^{5}$, Herman G P Swarts ${ }^{4}$, \\ Seong-Hyun Park ${ }^{6}$, Muhammad Hashim Raza ${ }^{7}$, Da Jung Jung ${ }^{8}$, Soo-Young Choi ${ }^{3}$, Sang-Heun Lee ${ }^{8}$, \\ Thomas Friedrich ${ }^{9}$, Gert Vriend ${ }^{5}$, Jan B Koenderink ${ }^{4}$, Un-Kyung Kim ${ }^{\star, 1,2,10}$ and Kyu-Yup Lee ${ }^{\star, 8}$
}

Hereditary sensorineural hearing loss is an extremely clinical and genetic heterogeneous disorder in humans. Especially, syndromic hearing loss is subdivided by combinations of various phenotypes, and each subtype is related to different genes. We present a new form of progressive hearing loss with migraine found to be associated with a variant in the ATP1A2 gene. The ATP1A2 gene has been reported as the major genetic cause of familial migraine by several previous studies. A Korean family presenting progressive hearing loss with migraine was ascertained. The affected members did not show any aura or other neurologic symptoms during migraine attacks, indicating on a novel phenotype of syndromic hearing loss. To identify the causative gene, linkage analysis and whole-exome sequencing were performed. A novel missense variant, c.571G $>$ A (p.(Val191Met)), was identified in the ATP1A2 gene that showed co-segregation with the phenotype in the family. In silico studies suggest that this variant causes a change in hydrophobic interactions and thereby slightly destabilize the A-domain of $\mathrm{Na}^{+} / \mathrm{K}^{+}$-ATPase. However, functional studies failed to show any effect of the $\mathrm{p}$.(Val191Met) substitution on the catalytic rate of this enzyme. We describe a new phenotype of progressive hearing loss with migraine associated with a variant in the ATP1A2 gene. This study suggests that a variant in $\mathrm{Na}^{+} / \mathrm{K}^{+}$-ATPase can be involved in both migraine and hearing loss.

European Journal of Human Genetics (2015) 23, 639-645; doi:10.1038/ejhg.2014.154; published online 20 August 2014

\section{INTRODUCTION}

Hereditary sensorineural hearing loss is one of the most common sensory disorders in humans, and it displays substantial clinical and genetic heterogeneity. It also displays different modes of inheritance in families, and despite the identification of many loci at which causative genes reside, a number of responsible genes still remain to be identified (http://hereditaryhearingloss.org/). Identification of deafness genes has been hampered in the traditional strategy of positional cloning because only few families may be linked to a particular locus, which makes it too difficult to narrow down the linked region or to precisely identify the critical interval in which to screen candidate genes by sequencing.

The advent of next-generation sequencing techniques has rapidly improved the process of identifying novel genes that cause diseases in humans. ${ }^{1-3}$ In particular, exome sequencing and the targeted sequencing of selected regions, when combined with information on co-segregation in families, have successfully identified genes that were difficult to find owing to a paucity of families available for a given linkage locus or owing to the difficulty of screening of all the candidate genes from a large linkage region. ${ }^{2}$

In this study, we applied exome sequencing in combination with genome-wide linkage analysis in an effort to identify the gene responsible for the phenotype featuring progressive hearing loss and migraine observed in a Korean family.

\section{PATIENTS AND METHODS}

Subjects and clinical evaluations

A family (KNUF-47) exhibiting an autosomal dominant inheritance pattern was ascertained at the Department of Otorhinolaryngology-Head and Neck Surgery, Kyungpook National University Hospital, Daegu, South Korea. A total of 12 individuals in three generations, including five affected and seven unaffected members, participated in this study (Figure 1). The proband of this family underwent detailed clinical evaluation including medical history, physical examination, audiologic testing, vestibular function test, and magnetic resonance imaging study. Pure-tone audiometry tests were performed in other members of the family and calculated as previously described. ${ }^{4}$ In addition, 200 unrelated Korean subjects with normal audiograms were used as controls.

${ }^{1}$ Department of Biology, College of Natural Sciences, Kyungpook National University, Daegu, South Korea; ${ }^{2}$ School of Life Sciences, KNU Creative BioResearch Group (BK21 plus project), Kyungpook National University, Daegu, South Korea; ${ }^{3}$ Department of Medicine, University of Pennsylvania, Philadelphia, PA, USA; ${ }^{4}$ Department of Pharmacology and Toxicology, Radboud University Nijmegen Medical Centre, Nijmegen Centre for Molecular Life Sciences, Nijmegen, The Netherlands; ${ }^{5}$ Radboud University Nijmegen Medical Centre, Nijmegen, The Netherlands; ${ }^{6}$ Department of Neurosurgery, Kyungpook National University Hospital, Daegu, South Korea; ${ }^{7}$ National Institute on Deafness and Other Communication Disorders (NIDCD), National Institutes of Health, Bethesda, MD, USA; ${ }^{8}$ Department of Otorhinolaryngology-Head and Neck Surgery, College of Medicine, Kyungpook National University, Daegu, South Korea; ${ }^{9}$ Institute of Chemistry, Technical University of Berlin, Berlin, Germany; ${ }^{10}$ Advanced Bio-resource Research Center (ABRC), Kyungpook National University, Daegu, South Korea

*Correspondence: Professor U-K Kim, Department of Biology, College of Natural Sciences, Kyungpook National University, Daegu 702-701, South Korea. Tel: +82 53 950 5353 ; Fax: +82 53953 3066; E-mail: kimuk@knu.ac.kr

or Professor K-Y Lee, Department of Otorhinolaryngology-Head and Neck Surgery, College of Medicine, Kyungpook National University, Daegu 700-721, South Korea. Tel: +82 53420 5777; Fax: + 8253423 4524; E-mail: kylee@knu.ac.kr

${ }^{11}$ These authors contributed equally to this work.

Received 27 October 2013; revised 25 June 2014; accepted 2 July 2014; published online 20 August 2014 
a

I

$\begin{array}{ll}\text { Marker } & \text { Position (cM) } \\ \text { D1S248 } & 139.02 \\ \text { D1S1653 } & 164.09 \\ \text { D1S1679 } & 170.84 \\ \text { D1S1677 } & 175.62 \\ \text { D1S2762 } & 179.10 \\ \text { D1S196 } & 181.49 \\ \text { D1S2799 } & 183.19\end{array}$

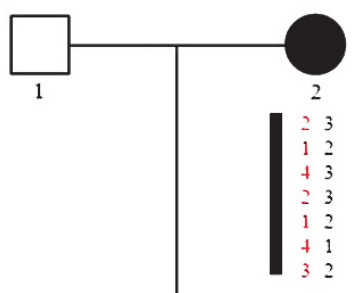

II
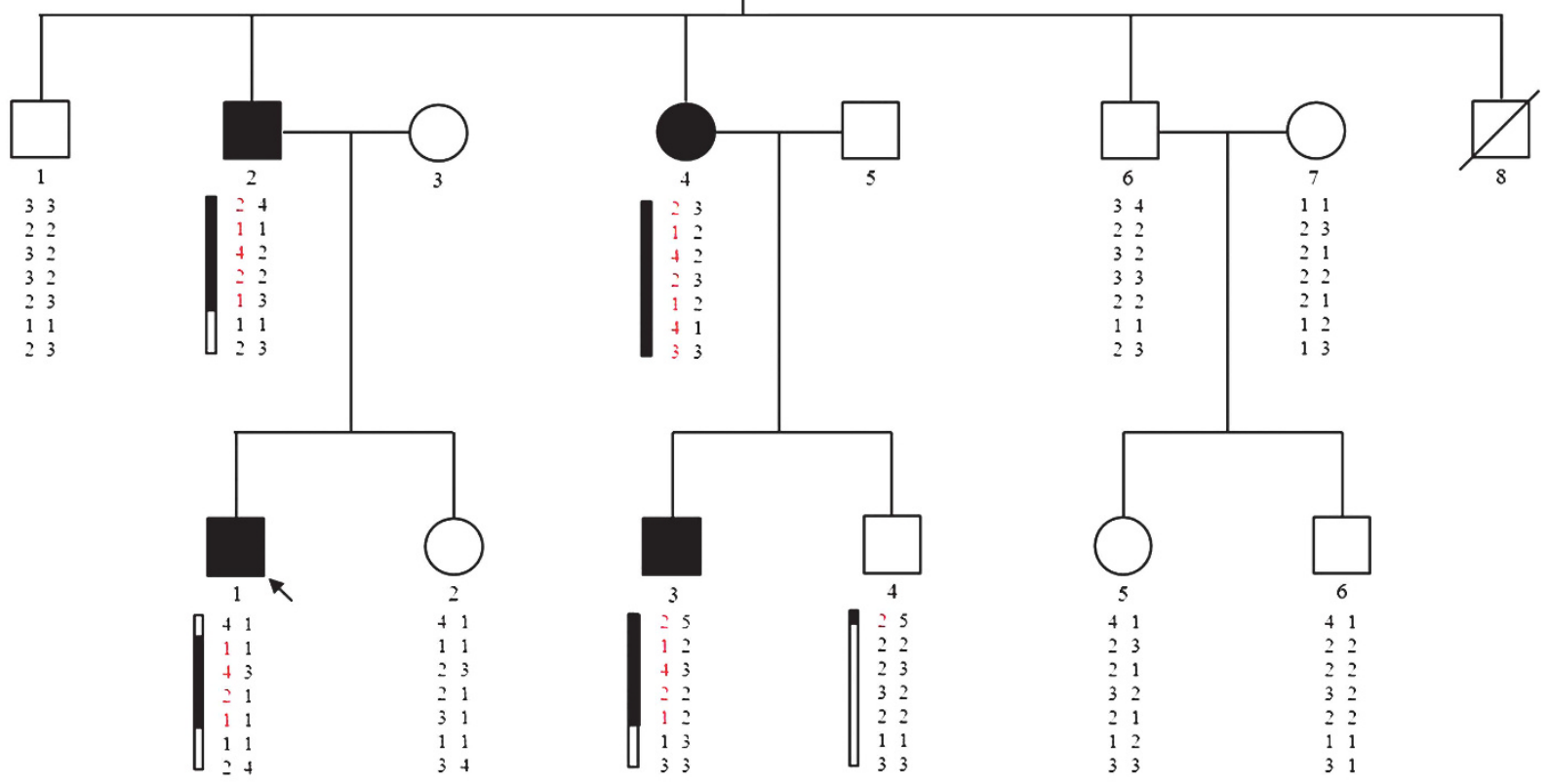

b

I-2, Female, $84 y$

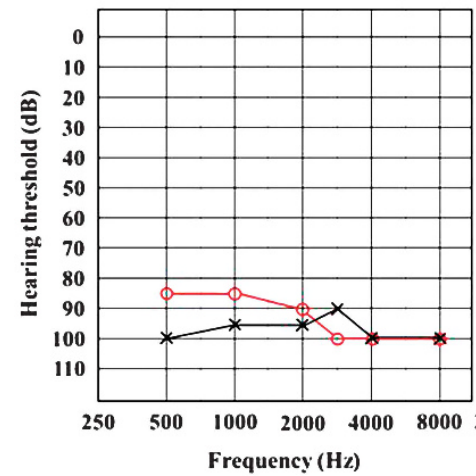

II-2, Male, 51 y

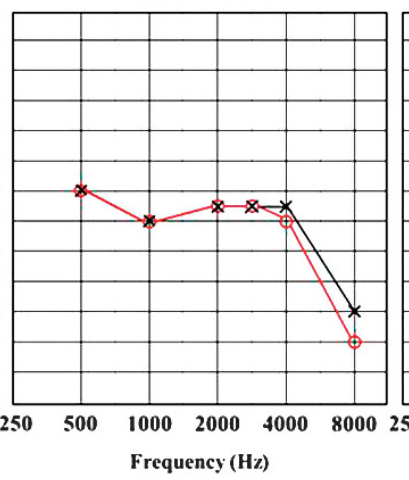

II-4, Female, 49y

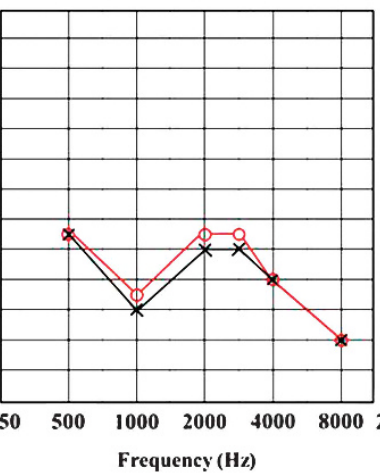

III-1, Male, 26y

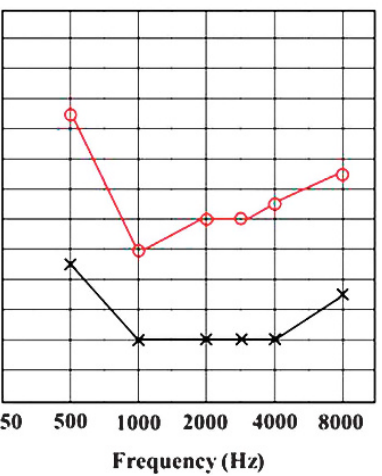

Figure 1 Clinical information and haplotype of the family KNUF-47. (a) Pedigree and haplotypes of the family KNUF-47. There is the three-generation family including 12 individuals who participated in this study. The affected haplotypes (black bars and red numbers) are co-segregated with DFNA49 locus on chromosome 1p13-1q24. Squares, male; circles, female; slashed symbol, deceased member; arrow, proband; black squares and circles, affected members. (b) Air conduction pure-tone audiograms for left and right ears of four affected members (I-2, II-2, II-4 and III-1). The horizontal axis and the vertical axis present pure-tone stimulus frequency $(\mathrm{Hz})$ and hearing threshold $(\mathrm{dB})$, respectively. Red lines connected by circles, right ear; black lines linked by cross marks, left ear.

\section{Linkage analysis}

Genomic DNA was extracted from peripheral blood from all the family members participating in the study using a FlexiGene DNA extraction kit (Qiagen, Hilden, Germany). A genome-wide linkage analysis was performed using 370 microsatellite markers with an average spacing of $10 \mathrm{cM}$ (ABI Prism Linkage Mapping Set, version 2.5, Applied Biosystems Corps., Foster City, CA, USA) as previously reported. ${ }^{5}$ The calculation of two-point log of odds (LOD) scores was carried out using MLINK program within the LINKAGE software package version 5.2. ${ }^{6}$ Linkage calculations were performed under the assumption of autosomal dominant inheritance, with $99 \%$ penetrance and a disease allele frequency of 0.001 . Haplotypes were constructed by genotyping microsatellite markers in parents and other family members.

\section{Whole-exome sequencing}

The exonic regions of the genome were analyzed using $10 \mu \mathrm{g}$ of genomic DNA from four individuals (II:2, II:4, III:1 and II:6, Figure 1). Genomic DNA was fragmented, adapters were attached, and the fragments were fractionated by 
size to $\sim 200-250$ base pairs. Target enrichment was performed using Nimblegen's SeqCap exome library v.2.0 (Roche NimbleGen, Madison, WI, USA), and the sequence of captured target DNA was sequenced using pairedend reads $(2 \times 200)$ on an Illumina HiSeq 2000 (Illumina, Inc., San Diego, CA, USA). The quality of the DNA products was confirmed using an Agilent Bioanalyzer (Agilent, Santa Clara, CA, USA), at all steps. Exome sequence data was aligned to the human reference genome hg19 (University of California, Santa Cruz, CA, USA), and bioinformatic analysis for filtering and detecting variations was performed using the DNAnexus platform (DNAnexus Inc., Mountain View, CA, USA, http://www.dnanexus.com). The variations with a low PHRED-encoded quality score $(<20)$ were eliminated. ${ }^{7-8}$ The apparently novel variants that were not listed in the single-nucleotide polymorphism database (dbSNP) (http://www.ncbi.nlm.nih.gov) or 1000 Genomes database (http://www.1000genomes.org) were selected for further analysis.

\section{Analysis of potential disease-causing variants}

Potential candidate variants were verified by co-segregation with the phenotype within this family based on Sanger sequencing. Primers for each variant were designed via Primer3 software (http://bioinfo.ut.ee/primer3-0.4.0/). PCR products were analyzed using an ABI 3130XL DNA sequencer (Applied Biosystems Corp.). Nucleotide sequence conservation analysis across species was performed with CLC Sequence Viewer v6.0.1 (CLC Bio, Aarhus, Denmark). The clinical and genetic information for the patient and the final candidate variant were submitted to the web-accessible Leiden Open Variation Database (http://www.LOVD.nl/ATP1A2; patient ID, KNUF-47).

\section{RNA extraction and RT-PCR}

Total RNA was extracted from adult mouse tissues including inner ear, brain, and testis with TRIzol reagent in accordance with the manufacturer's protocol. One microgram of each mRNA was used to synthesize cDNA with oligo(dT) primers in a $20-\mu \mathrm{l}$ reaction, of which $1 \mu \mathrm{l}$ was used for the PCR reaction. The DNA amplification was performed in a final volume of $25 \mu \mathrm{l}$, and PCR cycles conditions were $95^{\circ} \mathrm{C}$ for $15 \mathrm{~min}$, followed by 25 cycles of $94^{\circ} \mathrm{C}$ for $20 \mathrm{~s}, 55^{\circ} \mathrm{C}$ for $40 \mathrm{~s}, 72^{\circ} \mathrm{C}$ for $40 \mathrm{~s}$, with a final step of $72^{\circ} \mathrm{C}$ for $5 \mathrm{~min}$. PCR product $(5 \mu \mathrm{l})$ was separated using electrophoresis in $1.5 \%$ agarose gel and visualized with ethidium bromide staining.

\section{Molecular modeling}

The 3D structure of the ATP1A2 protein is unknown. However, the structure of the shark $\mathrm{Na}^{+} / \mathrm{K}^{+}$-ATPase (PDB file 2zxe) was solved experimentally and used as a template to build a homology model of the human protein. The template and model sequence share $87 \%$ sequence identity. The YASARA \& WHAT IF Twinset ${ }^{9}$ was used for model building and subsequent analysis using standard parameters.

\section{Generation of recombinant viruses}

cDNA fragments of the Na,K-ATPase $\alpha$-subunit were generated by Gatewayadapted PCR procedures according to the manufacturer's instructions (Invitrogen, Carlsbad, CA, USA). Entry clones were generated from the resulting PCR products by recombination with pDONR201 using Gateway Clonase II Enzyme Mix (Invitrogen).

The pFastbacdual transfer vector containing the mutant cDNAs was transformed into competent DH10bac Escherichia coli cells (Life Technologies, Breda, The Netherlands) harboring the baculovirus genome (bacmid) and a transposition helper vector. Upon transposition between the $\mathrm{Tn} 7$ sites in the transfer vector and the bacmid, recombinant bacmids were selected and isolated. ${ }^{10}$ Subsequently, insect $\mathrm{Sf} 9$ cells were transfected with recombinant bacmids using Cellfectin reagent (Life Technologies). After a 3-day incubation period, recombinant baculoviruses were isolated and used to infect $\mathrm{Sf} 9$ cells at a multiplicity of infection of 0.1. Four days after infection, the amplified viruses were harvested. Site-directed mutagenesis was performed using the single-base mutation system, DpnI method (Stratagene, La Jolla, CA, USA). The mutagenic primer (Biolegio, Nijmegen, The Netherlands) introduced the desired mutation in the $\alpha$-subunit. Following selection, mutant virus clones were verified by sequence analysis.
The pFastbacdual transfer vector containing the different (mutant) cDNAs was transformed to competent DH10bac Escherichia coli cells (Life Technologies) harboring the baculovirus genome (bacmid) and a transposition helper vector. Upon transposition between the Tn7 sites in the transfer vector and the bacmid, recombinant bacmids were selected and isolated. Subsequently, insect Sf9 cells were transfected with recombinant bacmids using Cellfectin reagent (Life Technologies). After a 3-day incubation period, recombinant baculoviruses were isolated and used to infect $S f 9$ cells at a multiplicity of infection of 0.1 . Four days after infection, the amplified viruses were harvested.

\section{Preparation of Sf9 membranes}

Sf9 cells were grown at $27^{\circ} \mathrm{C}$ in $\mathrm{T} 175$ monolayers and later in 500-ml shaking flasks cultures. For production of $\mathrm{Na}^{+} / \mathrm{K}^{+}$-ATPase, $1.5 .10^{6}$ cell $\mathrm{s} / \mathrm{ml}$ were infected at a multiplicity of infection of $1-3$ in the presence of $1 \%(\mathrm{v} / \mathrm{v})$ ethanol, and 0.1\% (w/v) pluronic F-68 (Sigma, Bornem, Belgium) in Xpress medium (Biowittaker, Walkersville, MD, USA) as described before. ${ }^{11}$ After 3 days, the Sf9 cells were harvested by centrifugation at $2000 \mathrm{~g}$ for $5 \mathrm{~min}$. Membranes were resuspended at $0{ }^{\circ} \mathrm{C}$ in $0.25 \mathrm{M}$ sucrose, $2 \mathrm{~mm}$ EDTA, and $25 \mathrm{~mm}$ Hepes/Tris ( $\mathrm{pH} 7.0$ ), and sonicated twice for $30 \mathrm{~s}$ at $60 \mathrm{~W}$ (Branson Power Company, Denbury, CT, USA). After centrifugation for $30 \mathrm{~min}$ at $10000 \mathrm{~g}$, the supernatant was collected and recentrifuged for $60 \mathrm{~min}$ at $100000 \mathrm{~g}$ at $4^{\circ} \mathrm{C}$. The pelleted membranes were resuspended in the above mentioned buffer and stored at $-20^{\circ} \mathrm{C}$.

\section{Western blotting}

Protein samples from the membrane fraction were solubilized in SDS-PAGE sample buffer and separated on SDS gels containing 10\% acrylamide. For immunoblotting, the separated proteins were transferred to Immobilon polyvinylidenefluoride membranes (Millipore Corporation, Bedford, MA, USA). The $\alpha$-subunit of the $\mathrm{Na}^{+} / \mathrm{K}^{+}$-ATPase was detected with the polyclonal antibody C356-M09. ${ }^{12}$

\section{$\mathrm{Na}^{+} / \mathrm{K}^{+}$-ATPase assay}

The ouabain-sensitive ATPase activity was determined using the radiochemical method of Koenderink et $\mathrm{al}^{13}$ For this purpose, 0.6-5 $\mu \mathrm{g}$ of Sf9 membranes were added to $100 \mu \mathrm{l}$ of medium, which contained $10-200 \mu \mathrm{M}\left[\gamma^{-32} \mathrm{P}\right]$-ATP (specific activity $20-100 \mathrm{mCi} / \mathrm{mmol}$, Amersham Pharmacia Biotech, Buckinghamshire, UK), $1.2 \mathrm{~mm} \mathrm{MgCl}_{2}, 0.2$ mм EGTA, $0.1 \mathrm{~mm}$ EDTA, $0.1 \mathrm{~mm}$ ouabain, $1 \mathrm{~mm} \mathrm{NaN}_{3}, 25 \mathrm{~mm}$ Tris- $\mathrm{HCl}(\mathrm{pH} 7.0)$ and various concentrations of $\mathrm{KCl}$ and $\mathrm{NaCl}$ in the presence and absence of $0.1 \mathrm{~mm}$ ouabain. After incubation for $30 \mathrm{~min}$ at $37^{\circ} \mathrm{C}$, the reaction was stopped by adding $500 \mu \mathrm{l} 10 \%(\mathrm{w} / \mathrm{v})$ charcoal in $6 \%(\mathrm{v} / \mathrm{v})$ trichloroacetic acid. After $10 \mathrm{~min}$ at $0{ }^{\circ} \mathrm{C}$, the mixture was centrifuged for $10 \mathrm{~s}(10000 \mathrm{~g})$. To $0.2 \mathrm{ml}$ of the clear supernatant, containing the liberated inorganic phosphate $\left.{ }^{32} \mathrm{Pi}\right), 3 \mathrm{ml}$ OptiFluor (Canberra Packard, Tilburg, The Netherlands) was added and the mixture was analyzed by liquid scintillation analysis. In general, blanks were prepared by incubating in the absence of membranes. The $\mathrm{Na}^{+} / \mathrm{K}^{+}$-ATPase activity is presented as the difference of activity in the absence and presence of ouabain.

\section{Ouabain-binding capacity}

Ouabain binding was determined as previously described by De Pont et al. ${ }^{14}$ Sf9 membranes $( \pm 50 \mu \mathrm{g})$ were incubated at $21^{\circ} \mathrm{C}$ in $50 \mathrm{~mm}$ Tris-acetic acid ( $\mathrm{pH}$ 6.0), and $1.2 \mathrm{~mm} \mathrm{MgCl}_{2}$ in a volume of $50 \mu \mathrm{l}$. After $30-60 \mathrm{~min}$ preincubation, $10 \mu$ of $\left[{ }^{3} \mathrm{H}\right]$-ouabain (specific activity $30 \mathrm{Ci} / \mathrm{mmol}$ ) was added and the mixture was incubated for $10 \mathrm{~s}$ at $21^{\circ} \mathrm{C}$. The protein was collected by filtration over a $0.8-\mu \mathrm{m}$ membrane filter (Schleicher and Schuell, Dassel, Germany). After washing twice with $2 \mathrm{ml}$ water, the filters were analyzed by liquid scintillation analysis. Data are corrected for the levels of aspecific ouabain binding obtained with mock-infected membranes.

\section{Analysis of data}

All data are presented as mean values with the SEM from three individual enzyme preparations. Differences were tested for significance by the Student's $t$-test. $\mathrm{K}_{0.5}$ values were determined by analyzing the plots using the non-linear curve fitting program (Hill equation function) of Origin 6.1 (Microcal, 
Northampton, MA, USA). The $\mathrm{Na}^{+}{ }_{0.5}$ and $\mathrm{K}^{+}{ }_{0.5}$ values were calculated via the Hill equation in Orgin, on the averaged data with SEM.

\section{RESULTS}

The proband, patient III-1, is a 26-year-old male who had a progressive hearing loss and migraine without aura. He was initially identified at age 20 years with progressive hearing loss that had begun at the age of 13 years and was not fluctuating. We obtained a clinical history from the proband and family members, and performed physical and neurological examinations, laboratory tests, vestibular function test, brain magnetic resonance imaging and audiologic tests on the proband. The diagnosis of migraine without aura fulfilled the International Headache Society International Classification of Headache Disorders II criteria. ${ }^{15}$ Migraines began at age 21 years, occurring an average of once a month. The proband's migraines lasted $24 \mathrm{~h}$ and exhibited pulsating at the right frontotemporal area accompanied with nausea, vomiting, and photophobia. He did not have any aura or neurologic symptoms, including dizziness, during migraine attacks. His laboratory tests, vestibular function tests including bithermal caloric test and rotatory chair test, and brain magnetic resonance imaging study were unremarkable (data not shown). Figure 1 shows the pedigree of the family KNUF-47 and the pure-tone audiograms of four affected members, who displayed moderate to severe hearing loss. These four individuals suffered from migraine without aura, but did not have any other symptoms or signs.

We screened the KNUF-47 family for linkage genome wide using 370 microsatellite markers. A region on chromosome 1q23 gave a suggestive LOD score of 2.09 at a recombination fraction of 0.00 . This LOD score was the maximum expected from simulation analysis, and this region was the only region genome wide with a LOD score that exceeded 2.0. Positive LOD scores suggestive of linkage were obtained for four markers in this region (Table 1). Haplotype analysis showed that all the affected members shared the same haplotype, and none of unaffected family memers carried this haplotype (Figure 1). Furthermore, the meiotic recombination events placed the disease locus between D1S248 and D1S196, corresponding to a region spanning $42.47 \mathrm{cM}$ containing $60 \mathrm{Mb}$ of DNA. These results strongly suggested that the region on chromosome $1 \mathrm{q} 23$ is likely to contain a gene causative for the hearing loss with migraine in this family.

Given the high number of genes in the region, we performed wholeexome sequencing in three affected members (II:2, II:4 and III:1) and one unaffected (II:6) member of the family. A total 3.48-7.93 gigabases (Gb) of mapped reads were obtained from each individual, resulting in 32-102-fold mean depth of coverage of the 879 kilobases $(\mathrm{kb})$ of exonic sequence in the linked region. More than $98 \%$ of the targeted

Table 1 Two-point LOD scores between hearing loss and each microsatellite marker on chromosome 1p13-1q24

\begin{tabular}{|c|c|c|c|c|c|c|c|}
\hline \multirow[b]{2}{*}{ Marker } & \multirow{2}{*}{$\begin{array}{l}\text { Marshfield genetic } \\
\text { position (cM) }\end{array}$} & \multicolumn{6}{|c|}{ Recombination fraction $(\Theta)$} \\
\hline & & 0.00 & 0.05 & 0.10 & 0.20 & 0.30 & 0.40 \\
\hline D1S248 & 139.02 & -5.79 & -0.57 & -0.14 & 0.14 & 0.15 & 0.06 \\
\hline D1S1653 & 164.09 & 1.13 & 1.00 & 0.86 & 0.58 & 0.30 & 0.08 \\
\hline D1S1679 & 170.84 & 2.09 & 1.92 & 1.73 & 1.32 & 0.88 & 0.41 \\
\hline D1S1677 & 175.62 & 0.83 & 0.72 & 0.61 & 0.39 & 0.18 & 0.04 \\
\hline D1S2762 & 179.10 & 1.96 & 1.79 & 1.61 & 1.23 & 0.80 & 0.36 \\
\hline D1S196 & 181.49 & -6.09 & -1.22 & -0.71 & -0.28 & -0.10 & -0.02 \\
\hline D1S2799 & 183.19 & -5.57 & -0.06 & 0.14 & 0.23 & 0.19 & 0.10 \\
\hline
\end{tabular}

Abbreviation: LOD, log of odds score. Bold type indicates the highest LOD score in this region. sequence in the linked region was covered in all of the four individuals (Supplementary Table 1). A total of 3997-8051 variants were detected in each individual. We first focused on nonsynonymous and heterozygous variants in the coding sequence in the linked region and identified 18 variants for follow-up based on the co-segregation of genotype with phenotype in these four family members. The dbSNP database of NCBI (http://www.ncbi.nlm.nih.gov) and 1000 Genomes databases (http://www.1000genomes.org) were used to exclude common polymorphisms. Following this filtering, two novel variants, c.571G $>$ A in the ATP1A2 gene (NM_000702.3) and c.916G > A in the ATP1A4 gene (NM_144699.3), were selected for additional analysis (Supplementary Table 2). We compared RNA expression between ATP1A2 and ATP1A4 in mouse tissues including inner ear, brain and testis. The ATP1A2 gene was expressed in inner ear and other two tissues, whereas the ATP1A4 was not expressed in inner ear (Supplementary Figure 1). As a result, we considered the c.571G $>$ A variant in the ATP1A2 gene as the only remaining candidate mutation. This missense variant changed guanine to adenine at the nucleotide position 571 (NP_000693.1), and it was predicted to result in a valine to methionine substitution (p.(Val191Met)). As expected from haplotype analysis, it showed co-segregation with the phenotype in the family (Figure 2). This variant was absent from both dbSNP and the 1000 Genomes database, and we did not find it in 200 Korean controls with normal hearing. This variant is located at a highly conserved amino-acid position across five species including mammals, birds, and fish (Figure 2). In addition, we analyzed the 23 exon-intron boundaries of the ATP1A2 gene by sequencing, and no variants except c. $571 \mathrm{G}>\mathrm{A}$ was detected in this gene in the KNUF-47 family.

Structural analysis of the c.571G $>$ A variant using a homology model showed that this variant could affect the structure and function of the protein. Residue Val191 is located in the so-called actuator domain (A-domain) (Figure 3). The side chain of valine 191 is buried in the core of this domain, where it contributes to the stability of the domain by making hydrophobic interactions with surrounding residues. The side chain of the substituted residue methionine is larger and polar, and will not optimally fit at the same position. As a result, this substitution appears likely to cause a change in hydrophobic interactions and a slight destabilization of this domain.

To study possible functional effects of the c.571G $>$ A variant, a PCR-based mutagenesis method was used to introduce the mutation into a human ATP1A2 cDNA. The wild-type and mutant $\mathrm{Na}^{+} / \mathrm{K}^{+}$ATPase $\alpha 2$ and $\beta 1$ subunits were cloned into recombinant baculoviruses and expressed in Sf9 insect cells. The membrane fractions of these cells expressing the recombinant ATPase proteins were isolated. Western blot analysis revealed similar expression levels for the wildtype $\mathrm{Na}^{+} / \mathrm{K}^{+}$-ATPase and the mutant (Figure 4 ).

To study whether the expressed proteins are functionally active, we performed inhibitor-binding studies. The $\mathrm{Na}^{+} / \mathrm{K}^{+}$-ATPase inhibitor ouabain binds in a pocket of the enzyme close to the cation-binding sites, ${ }^{11,16-17}$ and the binding of ouabain indicates that the protein is correctly folded and active. The ouabain-binding level for mutant and wild type was also similar (Figure 5a). In the presence of $100 \mu \mathrm{M}$ ATP, $5 \mathrm{mM} \mathrm{K}^{+}$and varying concentrations of $\mathrm{Na}^{+}$, the ATPase activity of the $\mathrm{Na}^{+} / \mathrm{K}^{+}$-ATPase was determined (Figure $5 \mathrm{~b}$ ). The apparent $\mathrm{Na}^{+}$ affinity of c.571G > A was not significantly changed compared with the wild-type enzyme $(6.35 \pm 0.24$ and $5.60 \pm 0.34 \mathrm{~mm}$, respectively). The ATPase activity of the $\mathrm{Na}^{+} / \mathrm{K}^{+}$-ATPase was determined in the presence of $100 \mu \mathrm{M}$ ATP, $50 \mathrm{~mm} \mathrm{Na}^{+}$and varying concentrations of $\mathrm{K}^{+}$(Figure 5c). The apparent $\mathrm{K}^{+}$affinity of c.571G $>$A was not significantly changed compared with the wild-type enzyme $(0.98 \pm 0.09$ and $0.94 \pm 0.12 \mathrm{~mm}$, respectively). 


\title{
GATCAACGCAGAGGAAGTGGTGGTGGGAGACCTGGTGGAGGTGAAGGGT GGAGACCGCGTCCCTGCTGACCTCCGGATCAT
}

\begin{abstract}
gat caacgcagaggaag tggt ggtgggagacctgg tggagatgaagggt ggagaccgcg gat caacgcagaggaag tggt ggtgggagac ctgg tggagatgaagggt ggagaccgcg

gat caac gcaga ggaag tggt ggtgg gagac ctgg tggagatgaagggt ggaga ccgcg tc....... gctg acctccgga tcat gat caacgcagaggaag tggt ggtgggagac ctgg tggagatgaaggggggaga ccgcg tccc tgc

gat caacgcagaggaag tggt ggtgggagacctgg tggagatgaagggt ggagaccgcg tccctgctgacctc cgga tcat gat caacgcagaggaag tggt ggtgggagac ctgg tggagatgaagggt ggagaccgcg tccc tgctgccctc cggatcat gat caacgcagaggaag tggt ggtgg gagacctgg tggagatgaagggt ggagaccgcggccctgctgacctccggatcat gat caacgcagaggaag tggt ggtgggagacctgg tggaggtgaagggt ggagaccgcg tccc tgctgacctccgga tcat gat caacgcagaggaag tggt ggtgggagacctgg tggaggtgaagggt ggagaccgcg tccc tgctgacctc cgga tcat gat caac gcagaggaag tggt ggtgg gagacctgg tggaggtgaagggt ggagac $\longrightarrow$ gat caacgcagaggaag tggt ggtgggagacctgg tggaggtgaagggt ggagaccgcgtcc $\rightarrow$ gat caacgcagaggaag tggt ggtgggagac ctgg tggaggtgaagggt ggagaccgcg tccc tgctgacct gat caacgcagaggaag tggt ggtgggagacctgg tggaggtgaagggt ggagaccgcg tccc tgctgacctccgga $\rightarrow$

aac gcagaggaag tggt ggtgg gagacctgg tggaggtgaagggt ggagaccgcg tccctgctgacctccggatcat gat caacgcagaggaag tggt ggtgggagac ctgg tggagatgaagggt ggagaccgcg tccctgctgacctccgga $\rightarrow$ gat caacgcagaggaag tggt ggtgg gagacctgg tggagatgaagggt ggagaccgcg tccctgctgacctccggatcat gat caacgcagaggaag tggt ggtgg gagacctgg tggagatgaagggt ggagaccgcg tccctgctgacctccggatcat gat caac gcagaggaag tggt ggtgggagacctgg tggagatgaagggt ggagaccgcg tccctgctgacctc cggatcat gat caacgcagaggaag tggt ggtgggagacctgg tggaggtgaagggt $\rightarrow$ gat caacgcagaggaag tggt ggtgggagac ctgg tggaggtgaagggt $\rightarrow$ gat caacgcagaggaag tggt ggtgggagac ctgg tggaggtgaagggt gga gat caacgcagaggaag tggt ggtgggagacctgg tggaggtgaagggt gga
\end{abstract}

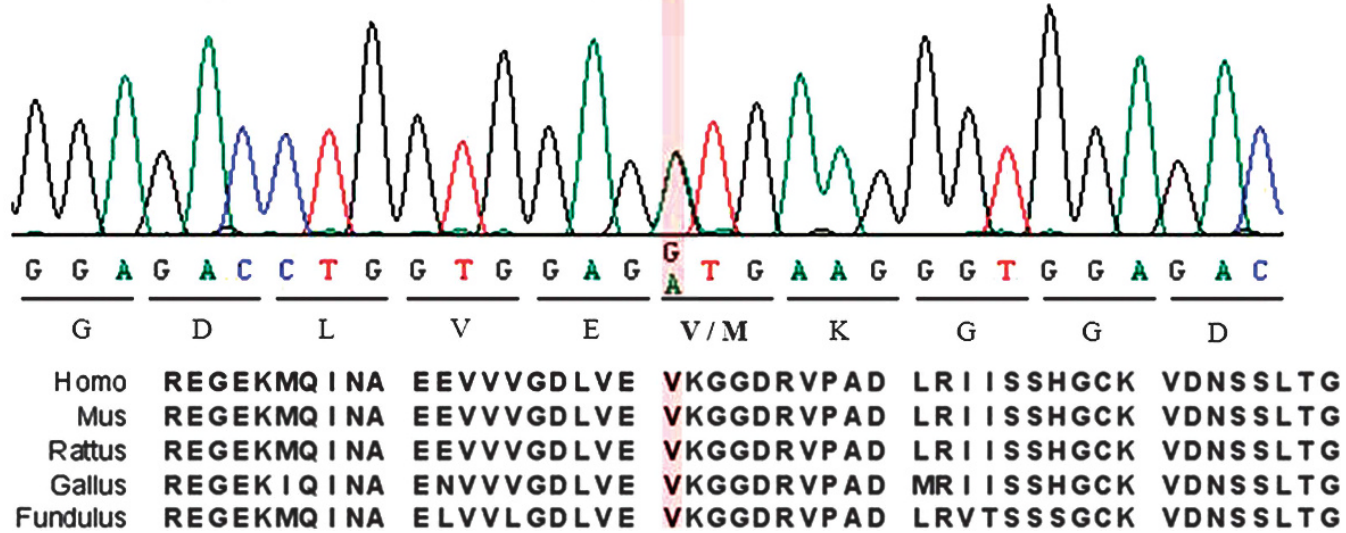

Figure 2 Identification of C.571G $>$ A in ATP1A2 showing co-segregation with hearing loss in the family KNUF-47. Top: the individual sequencing reads in the part of ATP1A2 screened by whole-exome sequencing. The actual read depth for this variant is from 39X to 101X. Blue reads, positive strands; green reads, negative strands; red bases, different bases from the reference sequence (black bases). Middle: the partial nucleotide sequences of ATP1A2 including c.571G $>$ A variant site confirmed by Sanger sequencing. All five affected members have heterozygous variant, c.571G $>$ A. Bottom: comparison of amino-acid sequences of the ATP1A2 across the five different species. The amino-acid sequences of various species including mammals, bird and fish are presented. Homo, Homo sapiens; Mus, Mus musculus; Rattus, Rattus norvegicus; Gallus, Gallus gallus; Fundulus, Fundulus heteroclitus; Red bar, variant position.

\section{DISCUSSION}

Mutations of the genes encoding the $\mathrm{Na}^{+} / \mathrm{K}^{+}$-ATPase $\alpha$-subunit (ATP1A2 and ATP1A3) have been described in three distinct human neurological disorders, familial hemiplegic migraine (FHM), rapidonset dystonia Parkinsonism, and alternating hemiplegia of childhood. ${ }^{18-22}$ These neurological disorders are dominantly inherited and caused primarily by missense mutations, which are thought to confer a mild hypomorphic loss-of-function.

In the present study, the proband suffered from hearing loss and migraines without aura, but he never accompanied other clinical symptoms. The inheritance pattern of the phenotype in this family was fully consistent with autosomal dominant. We performed targeted sequencing in the linked region of chromosome 1 and identified a heterozygous co-segregating novel missense variant in the ATP1A2 gene, which encodes the catalytic alpha 2 subunit $(\alpha 2)$ of $\mathrm{Na}^{+} / \mathrm{K}^{+}$-ATPase. Mutations in this gene have been previously described in FHM type 2, as well in sporadic hemiplegic migraine (SHM) ${ }^{23-25}$ Our results expand these previous findings. They suggest that ATP1A2-associated FHM may occur in a syndromic form, accompanied by progressive deafness. Our results also suggest that a search for progressive hearing loss in ATP1A2-associated migraine patients may be warranted.

The $\alpha$-subunit of $\mathrm{Na}^{+} / \mathrm{K}^{+}$-ATPase consists of four well-defined domains, actuator $(\mathrm{A})$, the phosphorylation $(\mathrm{P})$, nucleotide binding $(\mathrm{N})$, and ten transmembrane (M1-M10) domains, and represents common functional features of the P-type family of active cation transport proteins. The c.571G $>$ A variant is associated with the A-domain, which undergoes drastic structural rearrangement during the $\mathrm{E}_{1}-\mathrm{E}_{2}$ and $\mathrm{E}_{1} \mathrm{P}-\mathrm{E}_{2} \mathrm{P}$ transition of the $\mathrm{Na}^{+} / \mathrm{K}^{+}$-ATPase reaction cycle. ${ }^{26}$ As the amino-acid residues of the A-domain and P-domain are highly conserved in the P-type ATPases, the change of amino-acid residue could affect the mobility of the A-domain in the cycle. 
However, when we expressed human $\mathrm{Na}^{+} / \mathrm{K}^{+}$-ATPase $\alpha 2$ in concert with $\beta 1$ in insect cells, the c.571G $>$ A variant showed equal expression levels and ouabain binding to that of wild-type $\mathrm{Na}^{+} / \mathrm{K}^{+}$-ATPase, indicating that the functional expression of both enzymes is similar. In addition, we also failed to observe a significant difference between mutant and wild type in ATPase activity and $\mathrm{K}^{+}$and $\mathrm{Na}^{+}$affinity. When expressed in Xenopus laevis oocytes, the ATP1A2 variant did not alter voltage-dependent properties $\left(\mathrm{K}_{0.5}\right.$ for $\mathrm{K}^{+}, \mathrm{Q}-\mathrm{V}$ curve and

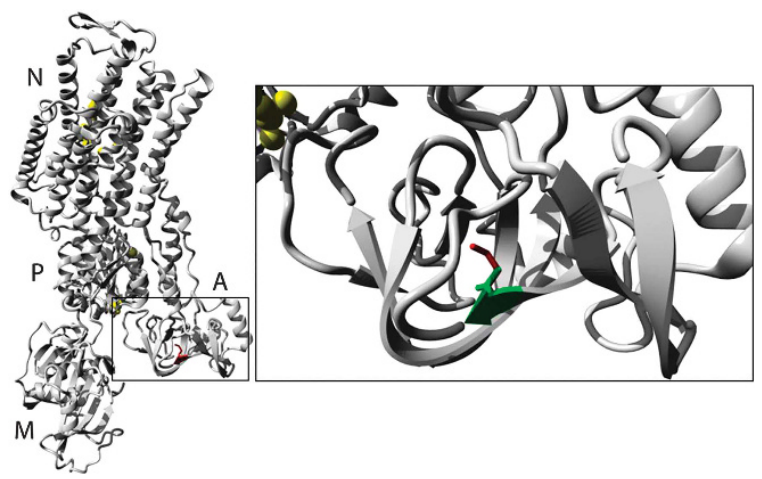

Figure 3 Evaluation of structural and functional effect of the c.571G $>$ A variant by molecular modeling. Left: the residue Val191 is located in the actuator domain, A domain (rectangle), of the ATPase. Right: magnified picture of the square region shows both the valine and methionine side chain, and difference in size between these two residues. Green, valine side chain; red, methionine side chain; $\mathrm{N}$, nucleotide-binding domain; $\mathrm{P}$, phosphorylation domain; A, actuator domain; $\mathrm{M}$, transmembrane domain.

V191M YFP- $\beta 1$ a2 wt

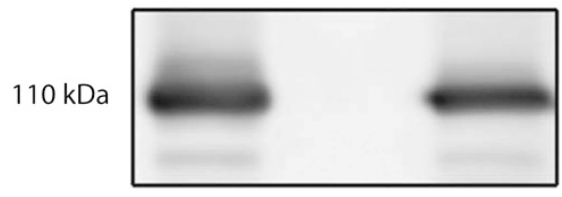

Figure 4 Expression of wild-type and variant $\mathrm{Na}^{+} / \mathrm{K}^{+}$-ATPase. Western blots of a $\mathrm{Na}^{+} / \mathrm{K}^{+}$-ATPase membrane preparation $(10 \mu \mathrm{g})$ isolated from infected Sf9 cells were blotted, and the presence of $\mathrm{Na}^{+} / \mathrm{K}^{+}$-ATPase $\alpha$-subunit was detected with antibody C356-M09 for the wild type, c. $571 \mathrm{G}>\mathrm{A}$ and YFP- $\beta 1$ (control). kinetics from transient currents) (data not shown). Moreover, also the currents determined for wild type and variant were similar, indicating equal plasma membrane expression (data not shown). However, it is possible that the c.571G $>$ A variant could have functional effects in the cells of the inner ear, due to specific protein interactions with, for example, glutamate transporters, that are not present in Sf9 cells or Xenopus laevis oocytes, or effects that become apparent only at $37^{\circ} \mathrm{C}$ and thus do not show up in Xenopus oocytes, which are kept at $18-21^{\circ} \mathrm{C}$.

Migraine is a very common neurologic disorder, ${ }^{27}$ with a prevalence of $6-18 \%$ in Western countries. ${ }^{28}$ Population-based family studies and twin studies support that importance of genetic factors in migraine, and mutations in genes including CACNA1A, ATP1A2, or SCN1A have been identified as the causes of the FHM and SHM. ${ }^{9,20,29-31}$ Thus to date, genes have been identified in rare subtypes of migraine, but not in the more common subtypes of migraine. In the present study, our results address that a more common type of migraine, migraine without aura, can be caused by a mutation of the ATP1A2 gene.

Our results suggest a link between migraine and hearing loss, perhaps consistent with other studies that have previously suggested an association between these two disorders. In a large populationbased study in Taiwan, an association between migraine and hearing loss has recently been reported. ${ }^{32}$ In addition, there have been previous reports of sudden hearing loss and migraine in Meniere's disease. ${ }^{33-36}$ However, the hearing loss developed in migraine patients at an older age, and their family members did not have hearing loss. Thus, it has not been clear whether the migraine and hearing loss share the same pathogenic cause in these cases. We note that the phenotype in our family is different from that in Meniere's disease, where fluctuating hearing loss has been reported with migraine.

Taken together, here we describe a previous unidentified syndrome featuring hearing loss and migraine associated with a novel variant in a gene encoding $\mathrm{Na}^{+} / \mathrm{K}^{+}$-ATPase. The $\mathrm{Na}^{+} / \mathrm{K}^{+}$-ATPase is a transmembrane protein that has a role in the transport of $\mathrm{Na}^{+}$and $\mathrm{K}^{+}$across the plasma membrane and maintaining cellular ion homeostasis, including cellular volume regulation, $\mathrm{pH}$ maintenance, and the generation of action potentials. ${ }^{37} \mathrm{~A}$ real function of $\alpha 2-\mathrm{Na}^{+}$, $\mathrm{K}^{+}$-ATPase in the nervous system is not fully understood. In the mouse inner ear, heterozygous deletion of $\alpha 2-\mathrm{Na}^{+} / \mathrm{K}^{+}$-ATPase results in progressive, age-related hearing loss and significant reduced endocochlear potentials. ${ }^{38} \mathrm{Na}^{+} / \mathrm{K}^{+}$-ATPase is a main
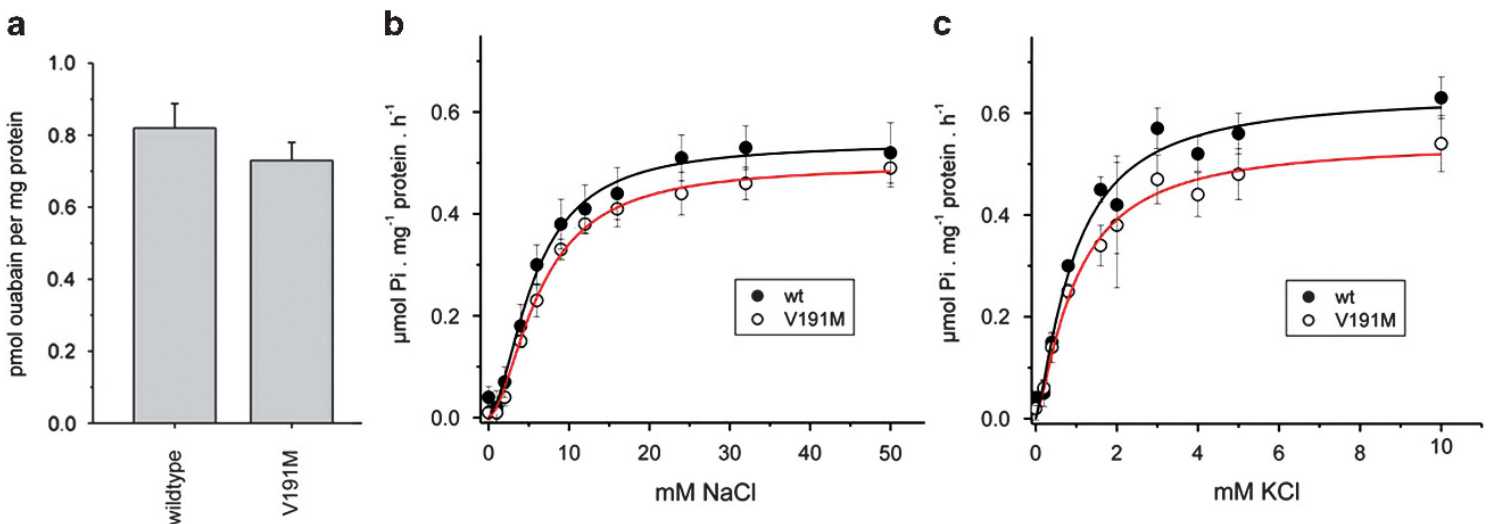

Figure 5 The properties of the wild-type $\mathrm{Na}^{+} / \mathrm{K}^{+}$-ATPase and the $\mathrm{c} .571 \mathrm{G}>\mathrm{A}$ variant. (a) Ouabain binding to wild type and $\mathrm{c} .571 \mathrm{G}>\mathrm{A}$ variant $\mathrm{Na}+/ \mathrm{K}^{+}$ -ATPase. $\mathrm{Na}^{+}$dependence (b), $\mathrm{K}^{+}$dependence (c), were measured in the ATPase activity assay. The assay conditions are as described in the Patients and methods section. 
modulator of glutamate uptake by coupling to the glutamate transporter. ${ }^{39} \mathrm{Na}^{+} / \mathrm{K}^{+}$-ATPase dysfunction causes impairment of glutamate transport, resulting in increases in extracellular glutamate in the synaptic cleft. ${ }^{40}$ In the cochlea, glutamate transporters have an essential role in the neural transmission between inner hair cells and auditory neurons, and glutamate transport antagonists produce a significant auditory threshold shift. ${ }^{40}$

In conclusion, ATPase channel dysfunction could cause irreversible progressive cochlear damage in addition to migraine, and we suggest that deficits in $\mathrm{Na}^{+} / \mathrm{K}^{+}$-ATPase can be involved in both migraine and hearing loss.

\section{CONFLICT OF INTEREST}

The authors declare no conflict of interest.

\section{ACKNOWLEDGEMENTS}

We are grateful to the family for their collaboration in this study. We thank Dr Susan Spiller for electrophysiological experiments, and Dr Drayna for critical comments on the manuscript. This research was supported by a grant of the Korea Health Technology R\&D Project through the Korea Health Industry Development Institute, funded by the Ministry of Health \& Welfare, Republic of Korea (grant number: HI12C1004(A121100)), and the TJ Park Science Fellowship funded by the POSCO Foundation of Korea (S-KO).

$1 \mathrm{Ng}$ SB, Turner EH, Robertson PD et al: Targeted capture and massively paralle sequencing of 12 human exomes. Nature 2009; 461: 272-276.

2 Ng SB, Nickerson DA, Bamshad MJ, Shendure J: Massively parallel sequencing and rare disease. Hum Mol Genet 2010; 19: R119-R124.

3 Mahboubi H, Dwabe S, Fradkin M, Kimonis V, Djalilian HR: Genetics of hearing loss: where are we standing now? Eur Arch Otorhinolaryngol 2012; 269: 1733-1745.

4 Choi SY, Park HJ, Lee KY et al: Different functional consequences of two missense mutations in the GJB2 gene associated with non-syndromic hearing loss. Hum Mutat 2009; 30: E716-E727.

5 Baek JI, Park HJ, Park K et al: Pathogenic effects of a novel mutation (c.664 681del) in KCNQ4 channels associated with auditory pathology. Biochim Biophys Acta 2011; 1812: $536-543$

6 Lathrop GM, Lalouel JM, Julier C, Ott J: Strategies for multilocus linkage analysis in humans. Proc Natl Acad Sci USA 1984; 81: 3443-3446.

7 Ewing B, Green P: Base-calling of automated sequencer traces using phred. II. Error probabilities. Genome Res 1998; 8: 186-194.

8 Ewing B, Hillier L, Wendl MC, Green P: Base-calling of automated sequencer traces using phred. I. Accuracy assessment. Genome Res 1998; 8: 175-185.

9 Krieger E, Joo K, Lee J et al: Improving physical realism, stereochemistry, and sidechain accuracy in homology modeling: four approaches that performed well in CASP8. Proteins 2009; 77:Suppl 9 114-122.

10 Luckow VA, Lee SC, Barry GF, Olins PO: Efficient generation of infectious recombinant baculoviruses by site-specific transposon-mediated insertion of foreign genes into a baculovirus genome propagated in Escherichia coli. J Virol 1993; 67: 4566-4579.

11 Qiu LY, Krieger E, Schaftenaar G et al: Reconstruction of the complete ouabain-binding pocket of $\mathrm{Na}, \mathrm{K}$-ATPase in gastric $\mathrm{H}, \mathrm{K}$-ATPase by substitution of only seven amino acids. J Biol Chem 2005; 280: 32349-32355.

12 Koenderink JB, Geibel S, Grabsch E, De Pont JJ, Bamberg E, Friedrich T: Electrophysiological analysis of the mutated $\mathrm{Na}$, K-ATPase cation binding pocket. $\mathrm{J}$ Biol Chem 2003; 278: 51213-51222.

13 Koenderink JB, Swarts HG, Hermsen HP, Willems PH, De Pont JJ: Mutation of aspartate 804 of $\mathrm{Na}(+), \mathrm{K}(+)$-ATPase modifies the cation binding pocket and thereby generates a high $\mathrm{Na}(+)$-ATPase activity. Biochemistry 2000; 39: 9959-9966.
14 De Pont JJ, Swarts HG, Karawajczyk A, Schaftenaar G, Willems PH, Koenderink JB: The non-gastric $\mathrm{H}, \mathrm{K}$-ATPase as a tool to study the ouabain-binding site in Na,K-ATPase. Pflugers Arch Eur J Physiol 2009; 457: 623-634.

15 Headache Classification Subcommittee of the International Headache Society. The International Classification of Headache Disorders: 2nd edition. Cephalalgia 2004; 24:Suppl 1 9-160.

16 Ogawa H, Shinoda T, Cornelius F, Toyoshima C: Crystal structure of the sodiumpotassium pump ( $\mathrm{Na}+, \mathrm{K}+$-ATPase) with bound potassium and ouabain. Proc Natl Acad Sci USA 2009; 106: 13742-13747.

17 Yatime L, Laursen M, Morth JP, Esmann M, Nissen P, Fedosova NU: Structural insights into the high affinity binding of cardiotonic steroids to the $\mathrm{Na}+, \mathrm{K}+$-ATPase. J Struct Biol 2011; 174: 296-306.

18 Cannon SC: Paying the price at the pump: dystonia from mutations in a $\mathrm{Na}+/ \mathrm{K}+$ ATPase. Neuron 2004; 43: 153-154.

19 de Carvalho Aguiar P, Sweadner KJ, Penniston JT et al: Mutations in the $\mathrm{Na}+/ \mathrm{K}+$ -ATPase alpha3 gene ATP1A3 are associated with rapid-onset dystonia parkinsonism. Neuron 2004; 43: 169-175.

20 De Fusco M, Marconi R, Silvestri L et al: Haploinsufficiency of ATP1A2 encoding the $\mathrm{Na}+/ \mathrm{K}+$ pump alpha2 subunit associated with familial hemiplegic migraine type 2 . Nat Genet 2003; 33: 192-196.

21 Haan J, Kors EE, Vanmolkot KR, van den Maagdenberg AM, Frants RR, Ferrari MD: Migraine genetics: an update. Curr Pain Headache Rep 2005; 9: 213-220.

22 Heinzen EL, Swoboda KJ, Hitomi $Y$ et al: De novo mutations in ATP1A3 cause alternating hemiplegia of childhood. Nat Genet 2012; 44: 1030-1034.

23 Castro MJ, Nunes B, de Vries B et al: Two novel functional mutations in the $\mathrm{Na}+, \mathrm{K}+$ -ATPase alpha2-subunit ATP1A2 gene in patients with familial hemiplegic migraine and associated neurological phenotypes. Clin Genet 2008; 73: 37-43.

24 De Cunto A, Bensa M, Tonelli A: A case of familial hemiplegic migraine associated with a novel ATP1A2 gene mutation. Pediatr Neurol 2012; 47: 133-136.

25 De Sanctis S, Grieco GS, Breda L et al: Prolonged sporadic hemiplegic migraine associated with a novel de novo missense ATP1A2 gene mutation. Headache 2011; 51: 447-450.

26 Jorgensen PL, Hakansson KO, Karlish SJ: Structure and mechanism of Na,K-ATPase: functional sites and their interactions. Annu Rev Physiol 2003; 65: 817-849.

27 Russell MB: Is migraine a genetic illness? The various forms of migraine share a common genetic cause. Neuro Sci 2008; 29(Suppl 1): S52-S54.

28 Lipton RB, Stewart WF: Migraine headaches: epidemiology and comorbidity. Clin Neurosci 1998; 5: 2-9.

29 Ophoff RA, Terwindt GM, Vergouwe MN et al: Familial hemiplegic migraine and episodic ataxia type- 2 are caused by mutations in the $\mathrm{Ca} 2+$ channel gene CACNL1A4. Cell 1996; 87: 543-552.

30 de Vries B, Freilinger T, Vanmolkot KR et al: Systematic analysis of three FHM genes in 39 sporadic patients with hemiplegic migraine. Neurology 2007; 69: 2170-2176.

31 Dichgans $M$, Freilinger T, Eckstein $\mathrm{G}$ et al: Mutation in the neuronal voltage-gated sodium channel SCN1A in familial hemiplegic migraine. Lancet 2005; 366 : 371-377.

$32 \mathrm{Chu}$ CH, Liu CJ, Fuh JL, Shiao AS, Chen TJ, Wang SJ: Migraine is a risk factor for sudden sensorineural hearing loss: a nationwide population-based study. Cephalalgia 2013. 33. 80-86.

33 Cha YH, Kane MJ, Baloh RW: Familial clustering of migraine, episodic vertigo, and Meniere's disease. Otol Neurotol 2008; 29: 93-96.

34 Lipkin AF, Jenkins HA, Coker NJ: Migraine and sudden sensorineural hearing loss. Arch Otolaryngol Head Neck Surg 1987; 113: 325-326.

35 Radtke A, von Brevern M, Neuhauser H, Hottenrott T, Lempert T: Vestibular migraine: long-term follow-up of clinical symptoms and vestibulo-cochlear findings. Neurology 2012; 79: 1607-1614.

36 Viirre ES, Baloh RW: Migraine as a cause of sudden hearing loss. Headache 1996; 36 : 24-28.

37 Mobasheri A, Avila J, Cozar-Castellano I et al: $\mathrm{Na}+, \mathrm{K}+$-ATPase isozyme diversity; comparative biochemistry and physiological implications of novel functional interactions. Biosci Rep 2000; 20: 51-91.

38 Diaz RC, Vazquez AE, Dou $\mathrm{H}$ et al: Conservation of hearing by simultaneous mutation of Na, K-ATPase and NKCC1. J Assoc Res Otolaryngol 2007; 8: 422-434.

39 Rose EM, Koo JC, Antflick JE, Ahmed SM, Angers S, Hampson DR: Glutamate transporter coupling to Na,K-ATPase. J Neurosci 2009; 29: 8143-8155.

40 Chen Z, Kujawa SG, Sewell WF: Functional roles of high-affinity glutamate transporters in cochlear afferent synaptic transmission in the mouse. J Neurophysiol 2010; 103: 2581-2586

Supplementary Information accompanies this paper on European Journal of Human Genetics website (http://www.nature.com/ejhg) 